Journal of Scientific Perspectives

Volume 3, Issue 1, Year 2019, pp. 1-10

E - ISSN: 2587-3008

URL: http://ratingacademy.com.tr/ojs/index.php/jsp

DOİ: $10.26900 /$ jsp.3.001

Research Article

\title{
ALGORITHM AND COMPLEX INFORMATION TECHNOLOGY FOR SOFTWARE PROJECTS RISKS EVALUATION
}

\author{
Vladlen SHAPO* \& Valeriy VOLOVSHCHYKOV** \& \\ Viktor GUZHVA *** \& Oryna MISHCHENKO**** \\ *National University "Odessa Maritime Academy", UKRAINE \\ E-mail:vladlen.shapo@gmail.com \\ ORCID ID: https://orcid.org/0000-0002-3921-4159 \\ ** National Technical University "Kharkiv Polytechnic Institute", UKRAINE \\ E-mail:valera@kpi.kharkov.ua \\ ORCID ID: https://orcid.org/0000-0003-4454-2314 \\ *** National Technical University "Kharkiv Polytechnic Institute", UKRAINE \\ E-mail: guzhva.v.a@gmail.com \\ ORCID ID: https://orcid.org/0000-0001-6832-4480 \\ **** National Technical University "Kharkiv Polytechnic Institute", UKRAINE \\ E-mail: arinochka012@gmail.com \\ ORCID ID: https://orcid.org/0000-0002-6783-673X
}

Received: 3 January 2019; Accepted: 28 January 2019

\begin{abstract}
Problem of software projects risks evaluation is identified. Review of modern approaches to risks evaluation is carried out. Analysis of software projects risks evaluation methods is performed. Analysis of sensitivity, scenarios method, simulation modeling, expert assessment are reviewed. Conclusions on importance of risks evaluation for "Software as a Service" software application systems at design stage are performed. It's proposed to perform software projects risks evaluation with expert assessment using by realization of corresponding information technology.

Mathematically risks evaluation technology is realized by Delphi method and ranking. Term of confidence interval is used as stopover criterion in computational procedure of Delphi method with the goal of coherent expert opinion obtaining. Calculating procedure envisages initial expert data correction by expert opinions revision and correction of expert group personnel. Consistency of expert opinions in mathematical technology on ranking method is checking with using of Kendall concordance coefficient, and its significance is evaluating on the basis of Pearson criterion. Presented mathematical apparatus formalizes solution of risks evaluation problem.
\end{abstract}

Methods of software projects risks evaluation and theirs mathematical technologies requires a big amount of calculating operations. Information support increases the rate and precision of such 
operations, ensures initial data and obtained results accumulation. Information support of software projects risks evaluation is realized as software application system. At development of software application system functional and nonfunctional requirements, database model and its structure were defined. Principles of object oriented analysis, data modeling, modern design patterns, CASE software tools were used.

It's proposed to realize software application system of information technology in accordance with client-server architecture, dedicated application server with distributed access rights with using of IDE NetBeans by PHP means under MySQL control. Conclusions on possibility of software application system using by performed validation and verification with expertise and PHP Unit using are made. Results of this work may be used for development of software projects risks evaluation information technology.

Keywords: Risk evaluation, software project, expert assessment, Delphi method, ranking method, requirements, model, structure, software application system.

\section{INTRODUCTION}

During performing of software projects (SP) at every stage [1] of software systems (SS) lifecycle (LC) it's possible to face to a greater or lesser extent with probable losses. For example, final SS quality decreasing, growing of costs at its developing, delay of finishing at developing, etc. Such losses occur as a consequence of risks, which arise in LC SS. That's why one of primary and inalienable problem, which has to be solved, is identification and evaluation of risks at SP realization.

Problem of software projects risks evaluation. At present time questions of risks evaluation are quite actual in different application fields. Without reference to any field of activity it's possible to claim on the base of analysis [2,3,4], that projects risks evaluation may be investigated with using of two approaches: qualitative and quantitative.

Main aspect of qualitative approach is in risks identification holding, risks evaluation and developing of actions on struggle with them. Quantitative analysis is based on toolkit of probability theory, mathematical statistics and theory of fuzzy set. Quantitative analysis in numeric dimension evaluates the influence of risky factors modifications to modification of project efficiency.

Significant growing of IT field, increasing of SP sizes, attitude to SP as to product with own specific technologic process leads to growing of SP risks evaluation problem. Accordingly to analysis [3, 4] it's possible to claim that SP risks may be categorized in multiple ways. One of possible alternatives: design risk, technical risk and business risk. This means that every group, which has own features, has to use own approaches for research [3, 4]. In turn this means that adaptation of existing approaches becomes important as from mathematical point of view as well as information point of view.

Therefore it's possible to claim, including relying to analysis [4, 5], that problem of SP risks evaluation is complex, multidimensional and needs to be solved.

Analysis of existing methods. As was mentioned above, methods of SP risks evaluation may be divided into quantitative and qualitative [6-8]. Quantitative methods are sensitivity analysis, method of scenarios and method Monte Carlo simulation [6, 7]. Generally believed that expert evaluation is qualitative method [8].

Sensitivity analysis is relatively simple method, which allows to clear up, which precisely factors it's possible to categorize to most risky. Most often this method apply for 
clarification of the level of project realization conditions modification influence to values of any indicator. During this analysis will be determined the level of project persistence against influence of external or internal factors.

Scenario analysis is method of non-formalized description of project risk, which includes evaluation of sensitivity of most significant factor for such project before set of factors modification, and also evaluation of common factors action possibility. At scenario analysis using may be calculated expected indicator value, standard deviation and coefficient of variation. Coefficient of variation for specific project must be compared to coefficients of variation for analogue projects. If coefficient of variation is greater than coefficient of variation of analogue project, it mentions about significant risk.

The goal of simulation is in reconstruction of behavior of the researched system on the base of analysis results of most significant relationships between its elements or, in other words, in developing of researched subject field simulator for different experiments carrying out. Simulation on Monte Carlo method allows to create mathematical model for project with uncertain parameters values. In turn with knowing of probability distribution of project parameters and correlation between parameters to obtain distribution of project risks.

Methods of interviewing are necessary for qualitative probability evaluation and risks after-effects for entire SPs. Risks interviewing with project interested sides and experts may become the first step in the process of qualitative risks analysis. Necessary information depends on type of probabilities distribution, which will be used. Qualitative SP risks analysis includes ranks positioning for identified risks. For identification and analysis of risks in expert evaluation the most often used methods are brainstorming, Delphi, control lists and ranking. Analysis and evaluation of risks are carrying out with the goal of converting of data, obtained during identification, into information, which allows to make important decisions. Main result of qualitative analysis process is the list of ranking risks with calculated evaluations.

Problem statement. Analysis of papers [1, 4, 5] shows, that qualitative SP risks evaluation is important stage in SS LC, in particular risks at design stage in such SS type as Software as a Service (SaaS). Accordingly, automation of solution of the task on qualitative risks evaluation in SP is actual. For solution of the task on SP risks evaluation the using of expert evaluation by Delphi and ranking methods is proposed in this paper. These methods increase the possibility of qualitative probable result obtaining, which is deprived of individual experts suggestions subjectivity. Procedures of these methods using take into consideration obtaining of results, which match to coordination of experts suggestions. Obtained results allow to rank risks and to display theirs indicators clearly.

Realization of SP risks evaluation procedure may allow to create effective procedures of risks control. Among other things, as a result, to avoid these risks or decrease them. Accordingly, problem of the SP risks evaluation remains quite actual. In conditions of permanent increasing of SP complexity and volumes the developing of corresponding information technologies becomes also important.

Thus, the purpose of this paper is developing of SP risks evaluation information technology.

\section{MAIN TEXT}

Technology of software projects risks evaluation. At risks evaluation of SaaS-type SPs in this paper following formalizations of Delphi method and ranking method are proposed.

Will assume, that $\mathrm{K}$ questions are highlighted, each of them is presented qualitatively in following form: $q_{k}, k=\overline{1, K}$. Let the group from $N$ experts is created for obtaining of answers. 
Each $i$-number expert forms self evaluation $S_{i}$ and gives numeric evaluation $q_{k}^{i}$ for $q_{k}$ question, using the scale from 1 to 10 . For the purpose of data analysis have to be calculated following indicators.

Group average evaluation:

$$
\bar{s}=\frac{1}{N} \sum_{i=1}^{N} s_{i} ;
$$

simple evaluations:

$$
a_{k}=\frac{1}{N} \sum_{i=1}^{N} q_{k}^{i}, k=\overline{1, K}
$$

weighted average evaluations:

$$
w_{k}=\frac{\sum_{i=1}^{N} s_{i} q_{k}^{i}}{\sum_{i=1}^{N} s_{i}}, k=\overline{1, K}
$$

medians:

$$
m_{k}=\operatorname{Me}\left\lfloor q_{k}^{i}, i=\overline{1, N}\right\rfloor k=\overline{1, K}
$$

confidence intervals $c_{k}=\left[\underline{c}_{k}, \bar{c}_{k}\right]$ on the base:

$$
\begin{gathered}
\underline{c}_{k}=q_{k}^{\min }+\frac{q_{k}^{\max }-q_{k}^{\min }}{4}, k=\overline{1, K ;} \\
\bar{c}_{k}=q_{k}^{\max }-\frac{q_{k}^{\max }-q_{k}^{\min }}{4}, k=\overline{1, K ;} \\
q_{k}^{\min }=\min _{i=1, N} q_{k}^{i}, k=\overline{1, K ;} \\
q_{k}^{\max }=\max _{i=1, N} q_{k}^{i}, k=\overline{1, K ;}
\end{gathered}
$$

lengths of confidence intervals: 


$$
l_{k}=\bar{c}_{k}-\underline{c}_{k}, k=\overline{1, K}
$$

Obtained results have to be analyzed by experts and in the case of necessity must be corrected, while generalized suggestion using length of confidence interval criterion will be obtained.

In accordance with results, obtained by Delphi method, it's possible to reach conclusions about the threat of risks, formulated as $K$ questions. For this $a_{k}$ must be ranked. Value $\max _{i=1, K} a_{k}$ is corresponding to the most dangerous risk, and so on. Respectively the reaction to such risks must be performed firstly. Other indicators are auxiliary and may be used in further development of risks control schedule.

Assuming that experts may perform risks ranking strictly by decreasing of importance and to assign to these risks the numbers from 1 to $K$, ranking method may be applied for SP risks evaluation. In this case the output information is $R_{i k}-$ the rank, which must be assigned by number $i$ expert accordingly to number $k$ risk.

Generalizing $R_{i k}$, it's necessary to calculate ranks $\bar{R}_{k}=\sum_{i=1}^{N} R_{i k}$, on the basis of which risks are ranked. Risks with the biggest rank is most dangerous.

At Rik analyzing it's recommended to define the coherence of experts suggestions. To realize this in this paper it's proposed to apply the Kendall concordance coefficient:

$$
W=\frac{12 \sum_{k=1}^{K}\left(\sum_{i=1}^{N} R_{i k}-\frac{N(K+1)}{2}\right)^{2}}{N^{2}\left(K^{2}-K\right)}
$$

With the purpose of concordance coefficient relevance verification it's proposed to use the Pearson criterion:

$$
\chi^{2}=N(K-1) W
$$

Information support of software projects risks evaluation. In contemporary conditions the solution of most tasks is impossible without using of modern information technologies, and the task of SP risks evaluation is not an exception. With the purpose of information technology SP risks evaluation software component realization the kit of functional and non-functional requirements was formed, corresponding database (DB) and system components representation model were designed.

Functional requirements are shown at Figure 1 as Unified Modeling Language (UML) precedents diagram. 
Figure 1 - Precedents diagram

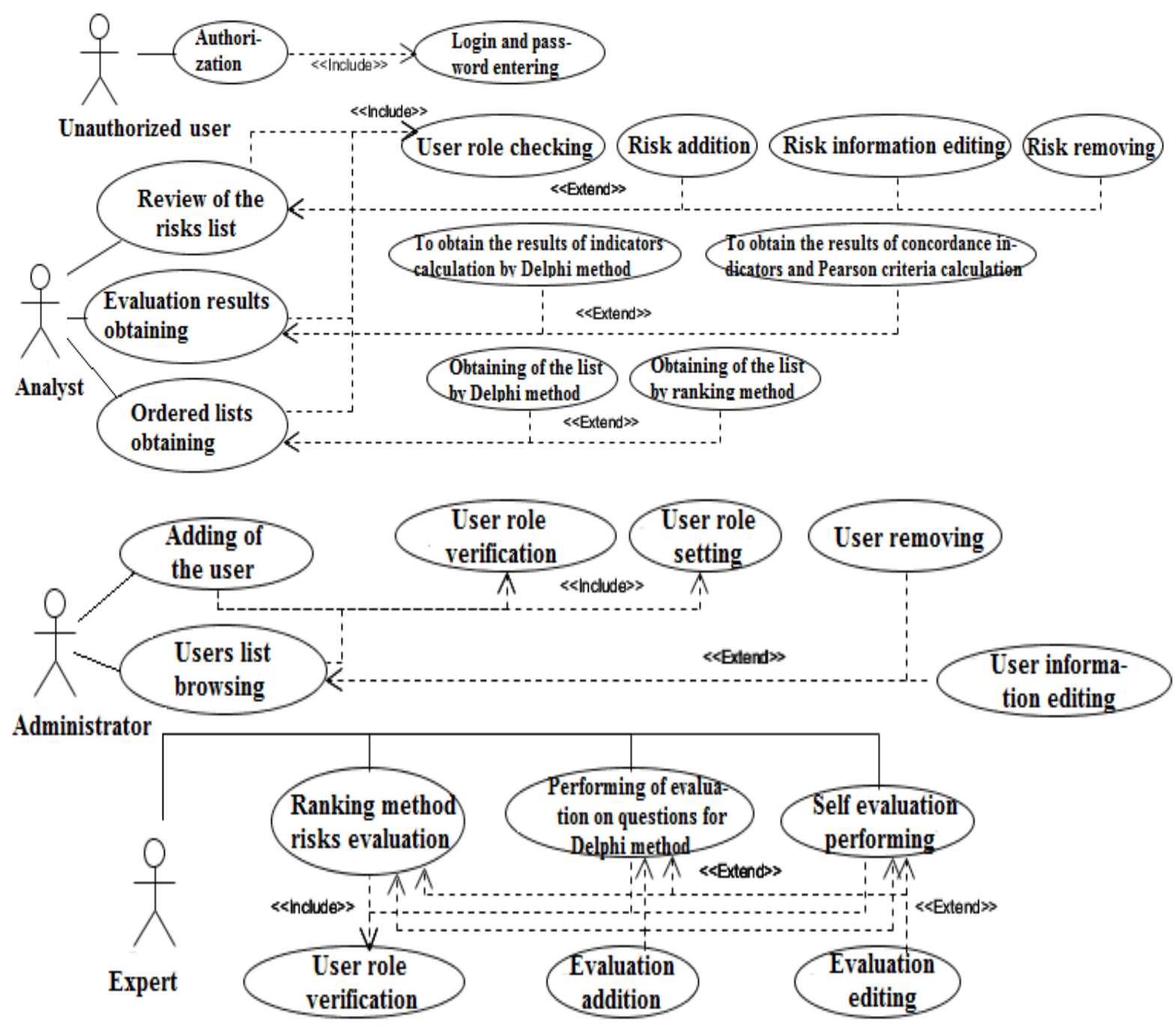

To key non-functional requirements should be included the following: user's interface must be minimized and intuitively comprehensible, software system must be convenient at using and to realize declared functionality.

Facilitation of information storing and processing is provided by DB means. In this work DB project is realized by ERWin CASE system means in the form of model, presented at Figure 2. Proposed structure provides the storing of output information (Risk), research results (QuestionsMarks, Delfi_Lap, Results_MethodDelfi, RangingConsensus, Rang_Lap, RangingConsensus, Rangs) and users' personal data (User, Expert, Analyst). 
Figure 2 - DB logical model

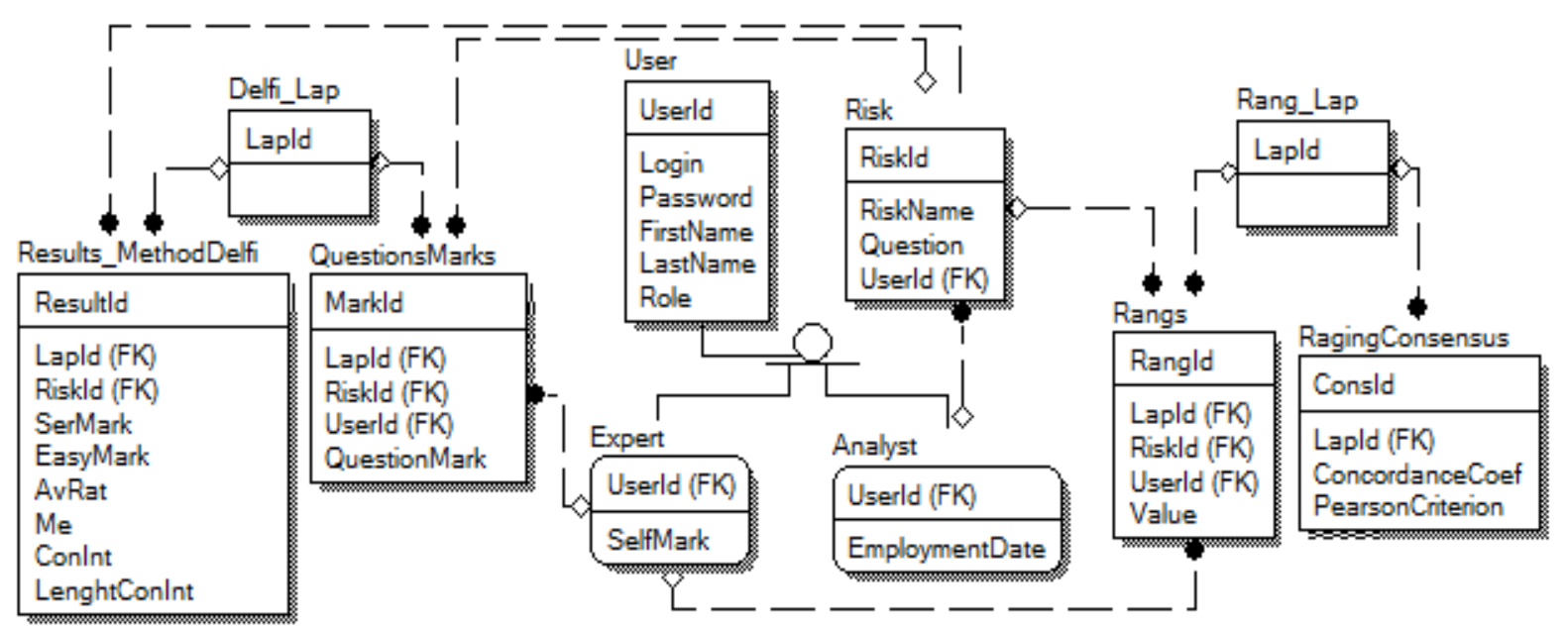

Components diagram, presented at Figure 3, illustrates physical presentations of system's components at the base of MVC pattern.

Figure 3 - Components' diagram

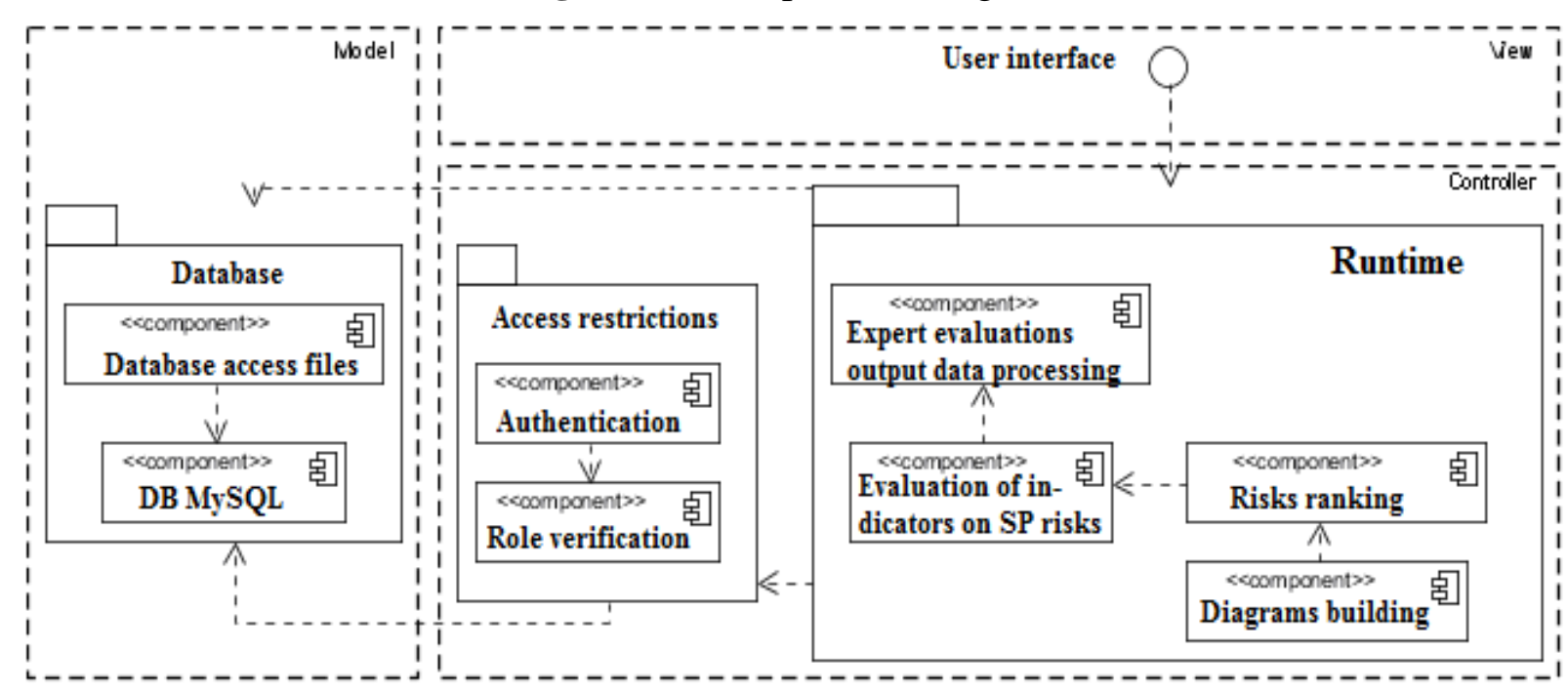

At Controller node the components for expert evaluations, calculation of indicators, risks ranking processing and building the diagrams at their base are deployed. This node also provides authentication and user role checking.

Information visualization forms are presented in user interface at View node.

Model node realizes software components on DB accessing.

Software system is realized in integrated development environment NetBeans by PHP language means and is functioning under control of MySQL DB control system. Software system validation is realized with expertise implementation. Verification is realized by means of module testing with PHPUnit using.

Algorithm, which describes roles, activities and sequence of actions for all participants of SPs evaluation process, is presented at figure 4. 
Figure 4-Roles, activities and sequence of SPs evaluation process participants actions

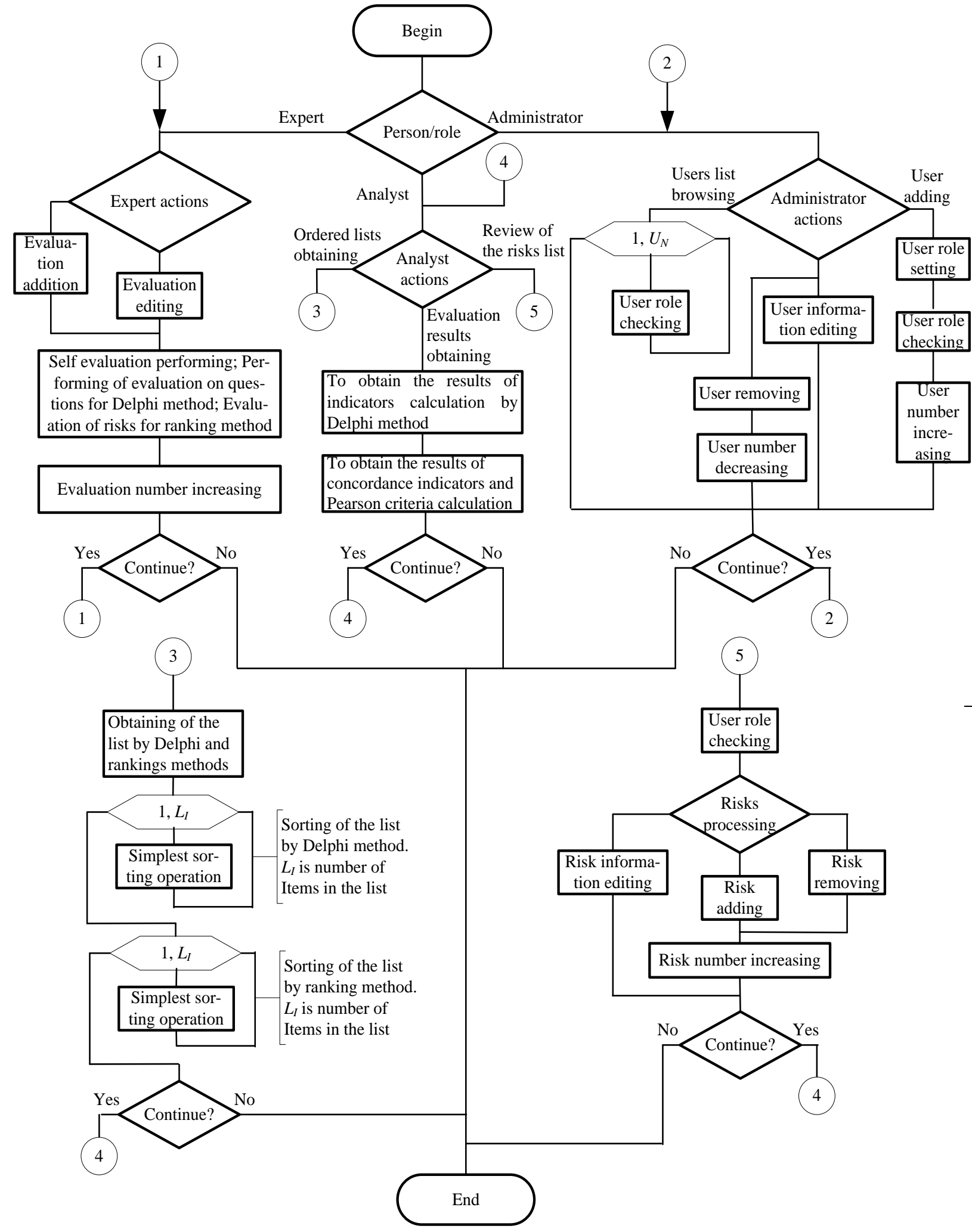


Form of expert survey is presented at Figure 5.

Figure 5 - Expert survey form

Expert panel / Risks evaluation (Delphi method)

Please, evaluate proposed risks in the range from 1 to 10 , where 1 is the least dangerous risk, 10 is the most dangerous risk:

\begin{tabular}{|l|l|l|l|l|l|l|l|l|l|}
\hline $\begin{array}{l}\text { Question } \\
\text { ID }\end{array}$ & \multicolumn{1}{|c|}{ Question } & & & \\
\hline $\mathbf{1}$ & What is the risk of project detailing insufficient level ? & & & & \\
\hline
\end{tabular}

\section{CONCLUSION}

Proposed formulas (1) - (11) describe mathematical model of risks evaluation process and its components. Created UML diagram and algorithm allow to automate processes of complex software projects evaluation from conceptual and practical points of view at design, database development and coding stages. This paper is logical follow-up to paper [12]. Complex technology of software projects risks evaluation is proposed in this paper. Software system is realized on the base of MVC pattern, described at the line of diagrams, complies to "client-server" architecture with dedicated application server and allows to automate the process of software projects risks evaluation. Proposed information technology allows to make rational decisions on the basis of expert data. Further elaboration will be guided to the direction of software projects risks control models developing and corresponding information support. 


\section{REFERENCES}

1. Elkina O. S. Ekonomika proyektnogo upravleniya: riski na raznykh stadíyakh zhiznennogo tsikla proyekta. Chast'1 [Economics of project management: risks at different stages of the project life cycle. Part 1]. Sibirskiy torgovo-ekonomicheskiy zhurnal [Siberian Trade and Economic Journal]. Omsk, Omsk Institute (branch) RGTEU, 2015. № 2 (20), pp. 12-15.

2. Shkurko V.E. Upravleniye riskami proyektov [Project risk management]. Ekaterinburg, Publishing house Ural. University, 2014. - 184 p.

3. Knight, F. Kh. Risk, neopredelennost' $i$ pribyl' [Risk, uncertainty and profit]. Moscow, Delo, 2003. - $360 \mathrm{p}$.

4. Smirnov A. A, Kovalenko A. V, Yakimenko N. N., Dorensky A. P. Problemy analiza i otsenki riskov informatsionnoy deyatel'nosti [Problems of analysis and evaluation of information activity risks]. Sistemi obrobki informatsiï [Systems of information processing]. Kharkov, Ivan Kozhedub Kharkiv University of Air Forces, 2016. - Vip. 3 (140), pp. 4042.

5. Kolodenkova A. E. Otsenka riskov sozdaniya programmnogo obespecheniya informatsionno-upravlyayushchikh sistem dlya vysokoriskovykh promyshlennykh predpriyatiy $\mathrm{v}$ usloviyakh interval'noy neopredelennosti iskhodnykh dannykh [Risk assessment of creating information management systems for high-risk industrial enterprises in the context of interval uncertainty of input data]. Vestnik Ufimskogo gosudarstvennogo aviatsionnogo tekhnicheskogo universiteta [Bulletin of Ufa State Aviation Technical University]. - Ufa, USATU, 2015. V.19, № 1 (67), pp. 192-199.

6. Project Management Institute. A Guide to The Project ManagementBody of Knowledge (PMBOK), 2001. - 211 p.

7. Lipaev V. V. Analiz i sokrashcheniye riskov proyektov slozhnykh programmnykh sredstv [Analysis and risk reduction of complex software projects]. - Moscow, SINTEG, 2005. $224 \mathrm{p}$.

8. Slobodsky A. L. Risks in personnel management [Risks in personnel management]. - St. Petersburg, SPSUEF, 2011. - 155 p.

9. Fatrell R. T., Schafer D. F., Schafer L. I. Upravleniye programmnymi proyektami. Prakticheskoye rukovodstvo po razrabotke uspeshnogo programmnogo obespecheniya [Software Project Management: Achieving Optimal Quality with Minimal Cost]. Moscow, Williams, 2003. - 1136 p.

10. Kantor M. Upravleniye programmnymi proyektami. Prakticheskoye rukovodstvo po razrabotke uspeshnogo programmnogo obespecheniya [Management of software projects. A practical guide to developing successful software]. - Moscow, Williams, 2002. - $176 \mathrm{p}$.

11. Bragina T. I., Tabunshchik G. V. Analiz podkhodov k upravleniyu riskami v programmnykh proyektakh s iterativnym zhiznennym tsiklom [Analysis of risk management approaches in software projects with an iterative life cycle]. Radioyelektronika, informatika, upravlínnya [Radio electronics, informatics, management]. - Zaporizhzhya, ZNTU, 2011. № 2. pp. 120124.

12. Mishchenko O. O, Volovshchikov V. Y., Shapo V.F. Modeli otsinky ryzykiv prohramnykh proektiv [Models of risk assessment of software projects]. XXVI Mizhnarodna naukovopraktychna konferentsiya MicroCAD-2018 [XXVI International Scientific and Practical Conference MicroCAD-2018]. - Kharkiv, NTU "KhPI", May 2018. - P. 25. 